\title{
THE CSÁTI REFI PROGRAM
}

\section{Author:}

László Horváth

Dr. Andor Enyedy Reformed Primary School, Kindergarten and Nursery School

E-mail adress of the author: iskola@csatirefi.hu

\section{Lectors:}

\author{
Katalin Mező(PhD.) \\ University of Debrecen \\ (Hungary) \\ Ferenc Mező (PhD.) \\ Eszterházy Károly University \\ (Hungary)
}

Horváth L. (2019): The CSÁTI REFI Program. Különleges Bánásmód, 5. (1). 91. DOI 10.18458/KB.2019.1.91

Supporting gifted students has always been a high priority for our school. Our institution created a Complex Talent Care Program based on the tender EFOP-3.3.7-17-2017-00018. We received a great support from Dr. Katalin Mező, Dr. Ferenc Mező, Ferenc Sarka and Dénes Kormos in this work and in training our teachers, therefore their kind assistance is much appriciated.

The shortened name of this program is: „Csáti Refi”. The „Csáti” expression refers to the town Mezőcsát where our school is located and where this program has been established, while the name "Refi” is an abbreviation for the Reformed religion. On the other hand in Hungarian the whole expression „Csáti Refi” is an acronym which refers to the main values of the program and the students' skills who participate in it.

Our main values are the next:

- Family (HUN: Család),

- Blessing (HUN: Áldás),

- Knowledge (HUN: Tudás),

- Justice (HUN: Igazságosság),

- Reformed (HUN: Református),

- Efficiency (HUN: Eredményesség),

- Development (HUN: Fejlódés),

- Innovative (HUN: Innovatív)

The complexity of the program is given by the fact that it was created from different subjects for grades 1-8, which guarantees talent care, guidance and talent bank for the gifted students. The aim of the program in the Reformed Primary School, Kindergarten and Nursery named after Dr. Enyedy Andor is to guarantee the unique support of the talented students and to motivate them to achieve a high level performance and later to become successful personalities.

We create the conditions for the students to achieve significant efficiency in all fields and help to develop the characteristics of their personality.

Our Talent Care Program include the next fields:

In the classroom: methodological and performance improvement by individual distinction.

Out of the classroom:

1. Real subjects: math, informatics

2. Human subjects: reading comprehension, games in mother tounge, tale writing,

history,

Hungarian language.

3. Skills:

craft,

art,

basketball, football.

4. Other:

physics,

digital,

domestic science,

biology,

English,

German, drama

Out-of-school: excursion, camping

As a part of the program in case of need we involve external training providers to support our students, their parents and our teachers. We believe that with this program we can support our students and their parents as well. 